Laporan Penelitian

\title{
Perbedaan efektifitas penutupan tubulus dentin antara pasta gigi yang mengandung bioaktif glass (novamin) dan strontium chloride
}

\author{
Profilia Shinta $^{1}$, Ketut Suardita ${ }^{2}$, Moch. Mudjiono \\ ${ }^{1}$ Mahasiswa PPDGS IlmuKonservasi Gigi \\ ${ }^{2}$ DosenDepartemenIlmuKonservasi Gigi \\ DepartemenIlmuKonservasi Gigi \\ FakultasKedokteran Gigi - UniversitasAirlangga \\ Surabaya - Indonesia
}

\begin{abstract}
ABSTRAK
Background : Dentinal hypersensitivity $(D H)$ is a painful clinical condition and is characterized by pain arising from exposed dentin in response to various stimuli. Various treatment modalities are available to treat dentinal hypersensitivity which include at-home and in-office treatment. At home treatment generally consists of a variety of dentrifices containing different constituents like strontium chloride and bioactive glass (Novamin). These agents cause occlusion of dentinal tubules thereby reducing hypersensitivity.Purpose: This study was to evaluate the effects of different desensitizing dentifrices on dentinal tubule occlusion by scanning electron microscopy (SEM) of strontium chloride and bioactive glass (Novamin) pastes in the treatment of dentinehypersensitivity (DH) Methods: sixteen extractedspecimens from bovine incisors teeth with randomized into 2 groups $(n=8)$. The crowns were removed from the root and the crown were sectioned longitudinally into two parts (in a mesiodistaldirection). The cervical toothwere resulting in two samples per tooth.Dentinal tubules were exposedand thesamples provided a $4 \mathrm{~mm} \times 4 \mathrm{~mm}$ area of exposed dentinal tubules.Group 1 (treated with strontium chloride), Group 2 (treated with bioactive glass (novamin))After each treatment for seven days, tubule occlusion on dentin were analyzed by scanning electron microscopy (SEM).The data were analyzed using "mann-whitneytest" ( $p<0.05)$. Result: Groups bioactive glass (novamin) showed tubule occlusion highest when compared with groups strontium chloride.Conclusion: bioactive glass (novamin) paste showed tubule occlusion highest with strontium chloride
\end{abstract}

Keywords: Bioactive glass, dentin hypersensitivity, dentinal tubules, strontium chloride

Korespondensi: Profilia Shinta; KetutSuardita; Moch. Mudjiono. DepartemenIlmuKonservasi Gigi, FakultasKedokteran Gigi, UniversitasAirlangga, Surabaya, Indonesia.E-mail:Profilia.shinta@yahoo.com.Telepon:+628124950319 


\section{PENDAHULUAN}

Hipersensitivitas dentin merupakan salah satu masalah gigi yang paling sering dijumpai. Hipersensitivitas dentin ditandai sebagai rasa nyeri akibat dentin yang terbuka jika diberikan stimulus termal, taktil, osmotik dan mekanis, seperti menyikat gigi, makan makanan manis dan asam, dan minuman dingin atau panas. Hal ini menyebabkan pasien merasa nyeri tajam yang singkat yang dikenal dengan hipersensitivitas dentin dan tidak berasal dari kelainan atau patologi gigi (Addy, 2002). Prevalensi hipersensitivitas dentinbervariasi dari terendah $4,5 \%$ sampai tertinggi $57 \%$.

Teori hidrodinamik yang disampaikan Brannstrom dan Astron pada tahun 1964 merupakan teori yang paling sering dipakai untuk menjelaskan mekanisme terjadinya hipersensitivitas dentin. Ketika terjadi stimulus eksternal dan kontak dengan dentin dapat memicu perubahan dialiran cairan dentin, teori ini menjelaskan bahwa pergerakan cairan yang cepat di dalam tubulus dentin (keluar dan kedalam) akan mengakibatkan distorsi ujung saraf di daerah pleksus saraf subodontoblas yang akan menimbulkan impuls saraf dan sensasi nyeri (Cummins, 2009).

Hipersensitivitas dentin bersifat reversible dan dapat ditangani dengan perawatan non-invasif yang sederhana. Diagnosa dan penyebab hipersensitivitas dentin harus ditegakkan dengan tepat agar perawatan yang diberikan memberikan efek yang tepat pula. Ada dua cara utama sederhana dalam perawatan hipersensitif dentin yaitu menghalangi syaraf perespon rasa nyeri dan menutup tubulus dentin untuk mencegah terjadinya mekanisme hidrodinamik (Orchardson 2000).

Salah satu cara perawatan hipersensitivitas dentin adalahdengan mencegah pergerakan cairan tubulus yang disebabkan karena adanya perubahan temperatur, fisik ataupun perubahan tekanan osmotik yang dapat menyebabkan hipersensitivitas(Addy, 2000).

Strontium chloridetelah direkomendasikan sebagai perawatan efektif untuk dentin hipersensitif berdasarkan presipitasi (penggumpalan) dalam tubulus dentin. Perawatan ini secara efektif menghilangkan hipersensitivitas dentin. Strontium dikatakan bekerja dengan mengendapkan strontium dan partikel deposit yang baik dari gabungan strontium pada permukaan dentin dan ke dalam tubulus dentin (Cummins 2010).Pada penelitian yang dilakukan dengan menggunakan beberapa pasta gigi yang mengandung strontium chloride dapat membantu penutupan tubuli dentin dan dilakukan pemeriksaan dengan menggunakan scanning electron microscopy (SEM) menunjukkan peningkatan penutupan tubuli dentin (Arrais, 2003).

$$
\text { Bioaktif glass (Novamin) }
$$
adalah campuran multi komponen inorganik yang terbuat dari elemenelemen silikon, kalsium, sodium, dan fosfor $(24,5 \% \mathrm{CaO}, 24,5 \% \mathrm{Na} 2 \mathrm{O}, 6,0 \%$ $\mathrm{P} 2 \mathrm{O} 5$, dan $45 \% \mathrm{SiO} 2)$ yang secara alami terdapat dalam tubuh. Bioaktif glass (Novamin), telah terbukti memiliki potensi untuk melepaskan kalsium dan fosfat pada keadaan yang lembab dimana partikel bioaktif glass(Novamin) dalam pasta gigi yang diformulasikan khusus ditunjukkan untuk menutup tubulus dentin.Oleh karena itu, dapat digunakan dalam pengobatan hipersensitivitas dentin (Natasha, 2011).

\section{BAHAN DAN METODE}

Pada penelitian ini menggunakan 16 (enam belas)gigi 
insisivus sapi yang diekstraksi setelah hewan tersebut dilakukan penyembelihan. Setelah diekstrasi gigi tersebut dibersihkan dari jaringan periodontal, bagian mahkota dan akar dipisahkan dengan carborundum disc kemudian semua mahkota gigi segera direndam dalam larutan saline. Kemudian dikelompokkan ke dalam 2 kelompok ( kelompok bioaktif glass (novamin) dan kelompok stontium chloride) dengan masing-masing kelompok berjumlah 8 gigi sapi. Bagian email gigi dihilangkan untuk mendapatkan permukaan dentin gigi,di belah longitudinal menjadi dua bagian (mesiodistal).Bagian cervical gigi dipakai dan akan menghasilkan dua sampel per gigi,Sampel dentin dibuat dengan ukuran $4 \mathrm{mmx} 4 \mathrm{~mm}$ dan permukaan gigi lain (bukan permukaan dentin) dilapisi cat kuku agar selama perlakuan tidak salah menempatkan bahan pasta gigi pada kedua kelompok. Sampel dentin diulas EDTA 24\% . 8 sampel dentin di aplikasi kan pasta gigi yang mengandung bioactif glass (novamin), direndam dalam saliva buatan dan disimpan dalam inkubator. 8 sampel dentin di aplikasi kan pasta gigi yang mengandung strontium chloride, direndam dalam saliva buatan dan disimpan dalam inkubator. Perlakuan dilakukan jam 08.00 wib dan 18.00 wib selama 7 hari.Dilakukan pemeriksaan penutupan tubulus dentin masingmasing kelompok dengan menggunakan Scanning Electron Microscopy (SEM) (Arrais, 2010).Dilakukan perhitungan penutupan tubulus dentin dengan cara (Mahajan, 2015) : 1. Dibuat sembilan kotak pada hasil gambaran SEM, dan dihitung penutupan tubuli dentin tiap kotaknya, dilakukan dengan 2-3 orang pengamat, 2. Bagian tubuli yang terdapat pada garis di ikutkan hanya pada satu bagian untuk menghindari pengulangan. Data yang diperoleh dari hasil penelitian dilakukan pengujian normalitas dan homogenitas. Uji normalitas menggunakan tes kormogorov smirnov sedangkan untuk uji homogenitas menggunakan levene's tes. Jika data terdistribusi normal dan homogen, maka dihitung secara statistik untuk mengetahui adanya perbedaan efektifitas penutupan tubulus dentin antara pasta gigi yang mengandung bahan bioaktif glass (Novamin) dan bahan strontium chloride memakai uji "Independent t-test". Tetapi jika data tidak terdistribusi normal atau tidak homogen, maka analisa statistik yang dipakai adalah "Mann-whitneytest".

\section{HASIL}

Dari penelitian mengenai penutupan tubulus dentin pada pasta gigi yang mengandung bioaktif glass (novamin ) dibandingkan dengan strontium chloride terhadap penutupan tubulus dentin, maka didapatkan gambaran penutupan tubulus. Dapat dilihat pada kelompok bioaktif glass (novamin) terdapat penutupan tubulus yang lebih banyak dibandingkan dengan kelompok strontium chloride (lihat gambar). Selain itu juga didapatkan nilai rata-rata dari penutupan tubulus dentin pada masing-masing kelompok (Tabel 1). 

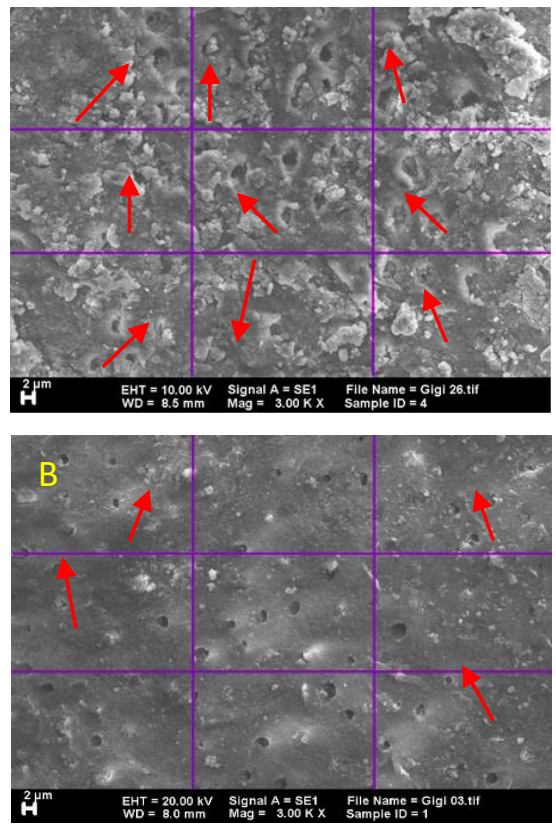

Gambar. Penutupan tubulus dentin pada masing-masing kelompok (SEM pembesaran 300x), tanda $\rightarrow$ menunjukkan penutupan tubulus dentin pada kelompok: A. Bioaktif glass (novamin), B. Strontium chloride

Hasil uji distribusi data dengan menggunakan uji statistik Kolmogorov Smirnov Test pada semua kelompok pengukuran kedalaman lesi demineralisasi mempunyai nilai $\mathrm{p}>0,05$. Hal ini menunjukkan bahwa semua kelompok pengukuran mempunyai distribusi data yang normal. Sedangkan untuk hasil uji homogenitas varians dengan menggunakan uji statistik Levene Test mempunyai nilai $\mathrm{p}<0,05$. Hal ini menunjukkan bahwa data pada kedua kelompok tidak mempunyai varians yang homogen. Setelah dilakukan uji normalitas dan homogenitas maka selanjutnya digunakan "Mann-whitneytest" untuk mengetahui perbedaan secara keseluruhan kelompok. Hasil analisis pada keseluruhan kelompok terdapat perbedaan penutupan yang signifikan yaitu $\mathrm{p}<0,05$. hasil uji beda antar kelompok (bioaktive glass dan strontium chloride), mempunyai nilai $\mathrm{p}<0,05$. Hal ini menunjukkan bahwa ada perbedaan yang bermakna antara kelompok (Tabel 2). 


\begin{tabular}{|c|c|c|}
\hline Kelompok & N & X \\
\hline Novamin & 8 & 29,1250 \\
\hline Strontium & 8 & 14,2500 \\
\hline
\end{tabular}

Tabel 1. Hasil Rerata dan Standar Deviasi penutupan tubulus dentin

\begin{tabular}{|c|c|c|}
\hline Kelompok & Novamin & Stontium \\
\hline Novamin & & $0,01^{*}$ \\
\hline Strontium & $0,01^{*}$ & \\
\hline \multirow{2}{*}{$* \mathrm{p}<0,05:$ terdapat perbedaan yang bermakna }
\end{tabular}

Tabel 2. Hasil Uji Beda penutupan tubulus dentin

\section{DISKUSI}

Dari penelitian mengenai perbedaan efektifitas penutupan tubulus dentin antara pasta gigi yang mengandung bioaktif glass (novamin) dan strontium chloride terdapat perbedaan yang bermakna $(\mathrm{p}<0,05)$ antara kelompok bioaktif glass dan strontium chloride, dengan menggunakan "mannwhitneytest". Sebelum dilakukan uji beda antar kelompok bioaktif glass (novamin) dan strontium chloride, masing-masing kelompok pengukuran diuji distribusi datanya dengan uji statistik Kolmogorov Smirnov Test dan homogenitas variansnya dengan uji statistik Lavene Test.

Dentin hipersensitif merupakan suatu kondisi yang manimbulkan gejala dari rasa nyeri ringan hingga tajam bila gigi terkena stimuli eksternal seperti taktil, termal dan kirniawi. Selain itu faktor atrisi, abrasi dan erosi sangat berperan menimbulkan terbukanya tubuli sebagai penyebab terjadinya hipersensitivif.
Mekanisme sensitivitas dentin yang paling banyak diterima adalah teori hidrodinamik yang dikemukakan oleh Brannstrom, yang mana aliran cairan dalam tubulus dentin diubah oleh rangsangan termal, taktil, atau kimia dekat permukaan terbuka dari tubulus. Gerakan ini mengaktifkan saraf pada ujung bagian dalam tubulus dentin atau lapisan luar pulpa. Oleh karena itu, salah satu faktor risiko terbesar sensitivitas adalah terbukanya tubulus dentin (Absy et al, 1987).

Pengobatan hipersensitivitas dentin harus sesuai dengan tingkat keparahannya. Misalnya, menyarankan pasien untuk menggunakan pasta gigi desensitisasi dua kali sehari sesuai untuk pasien dengan sensitivitas ringan, tetapi tidak sesuai untuk pasien dengan hipersensitivitas dentin yang parah. Bahan yang terkandung dalam pasta gigi diharapkan dapat bereaksi dengan ion kalsium dan menbentuk kristal yang dapat menutup tubuli dentin dan mencegah aliran cairan melalui tubuli (Cohen, 2002). 
Pasta gigi yang mengandung srontium chloride $\left(\mathrm{SrCl}_{2}\right)$ yang dibentuk oleh strontium hidroxyde/ strontium carbonat $\left(\mathrm{Sr}(\mathrm{OH})_{2}\right)$ dan $2 \mathrm{HCl}$ menghasilkan strontium chloride $\left(\mathrm{SrCl}_{2}\right)$ dan $2 \mathrm{H}_{2} \mathrm{O}$ membentuk bentukan kristal-kristal kecil yang mengendap pada permukaan dentin yang dapat mengurangi hipersensitivitas dentin, tetapi bahan tersebut akan mudah rusak (Arnold, 2015).

Bioaktif glass (novamin) dapat menutup tubulus dentin dengan adanya lapisan yang terbentuk ketika bahan aktif kalsium sodium fosfosilikat bereaksi dengan media cair (saliva), reaksi tersebut akan menghasilkan ion kalsium dan fosfat, dalam beberapa saat akan terbentuk hidroksikarbonat apatit. Partikel kalsium sodium dan hidrokxycarbonat apatite akan membentuk lapisan pada dentin. Gambaran scanning electron microscope pada preparat perlakuan dengan Novamin selama 7 hari menunjukan tubulus dentin yang terlapisi. Selain itu, kalsium dan fosfat yang terdapat dalam saliva buatan akan membentuk lapisan kalsium fosfat. Ketika reaksi partikel berlanjut dan deposisi kalsium fosfat terjadi, lapisan ini akan menjadi hidroxycarbonat apatit. Partikel - partikel ini akan melekat pada permukaan gigi dan terus melepaskan ion - ion dan melakukan proses remineralisasi pada permukaan gigi segera setelah diaplikasikan. Partikel ini telah dibuktikan secara studi in-vitro, melepaskan ion - ion dan berubah bentuk menjadihyaroxycarbonate apatite(HCA) selama 1 minggu. Pada akhirnya partikel-partikel ini akan berubah seluruhunya menjadi HCA yang merupakan mineral dari gigi dan tulang tubuh manusia dan menghasilkan $80 \%$ occludance tubular dan desensitisasi (Natasha M, 2011).
Kedua pasta gigimemiliki kemampuan dalam penutup tubulus dentin dan pada kedua pasta gigi tersebut memiliki kandungan bahan aktif yaitu Strontium chloride dan Novamin. Keduanya memiliki kemampuan yang sama untuk membentuk suatu presipitat pada tubulus dentin, tetapi bahan pada pasta gigi yang mengandung Novamin lebih baik dalam menutup tubulus dentin dibandingkan dengan pasta gigi yang mengandung Strontium chloride karena selama Novamin berkontak dengan saliva dan aplikasi pasta gigi berlangsung maka proses pembentukan kalsium fosfat akan terus berlangsung sehingga pengendapan pada tubulus dentin akan semakin bertambah dan partikel - partikel ini akan melekat pada permukaan gigi dan terus melepaskan ion - ion dengan melakukan proses remineralisasi pada permukaan gigi segera setelah diaplikasikan, pada akhirnya partikel-partikel ini akan berubah seluruhnya menjadi HCA yang merupakan mineral dari gigi. Sedangkan Strontium chloride membentuk bentukan kristal-kristal kecil yang mengendap pada permukaan dentin yang dapat mengurangi hipersensitivitas dentin, tetapi bahan tersebut akan mudah rusak (Arnold 2015).

\section{KESIMPULAN}

Pasta gigi yang mengandung bioactif glass (Novamin) penutupan tubulus dentin lebih baik dari pada pasta gigi yang mengandung strontium chloride. 


\section{DAFTAR PUSTAKA}

1. Absi EG, Addy M, Adams D. 1997.Dentine hypersensitivity. A study of the patency of dentinal tubules in sensitive and non-sensitive cervical dentine. J Clin Periodontol.;14:280-4.

2. Adioro S. 2013.Penggunaan Resin Komposit Dalam Bidang Konservasi Gigi. Surabaya. Revka petra Media.p: 72

3. Addy M,.2002.Dentine hypersensitivity: new perspective on an old problem. Int J Dent.52:367-75

4. Addy M. 2000.Dentine hypersensitivity: definition, prevalence distribution and aetiology.Tooth wear and sensitivity.London, UK:Martin Dunitz.p.239-48

5. Allan I, Newman H, Wilson M. 2001. Antibacterial activity of particulate bioglass against supra-and subgingival bacteria.Biomaterials;22(12):1683-7

6. Arnold W.H, M. Prage, EA. Naumova.2015. Effectiveness of various toothpastes on dentine tubule occlusion. Department of Biological and Material Sciences in Dentistry

7. Arrais CA, Carolina Diniz Micheloni. Occluding effect of dentifrices on dentinal tubules,2003 Department of Restorative Dentistry/Operative Dentistry, Piracicaba School of Dentistry,UNICAMP. Av. Limeira, \#901, Piracicaba, SP 13414-900, Brazil

8. Anusavice, KJ.2003.Philip's Science of Dental Material,11th ed, WB Saunders Co., Philadelphia-LondonToronto,p:21-395

9. Brännström M, Aström A. 1972The hydrodynamics of the dentine, its possible relationship to dentinalpain. Int Dent J.,22:219-27

10. Cummins D. Dentin hypersensitifity.2009. From diagnosis to breakthrough therapy for everyday sensitivity relief.J Clin dent.;20:1-9

11. Cohen S, Burn RC.2002. Pathways of the pulp, 8 th Ed, Mosby inc, St LouisLondon-Phila delphia, p:411-54

12. Davis WB, Winter PJ,1997. Dietary erosion of adult dentine and enamel. Protection with a toothpaste. Br Dent J;143(4):116-9.

13. Fais LM, Marcello CC, Silva RH, Guadlianoni DG, Pinelli LA.2010. Human teeth Versus Bovine Teeth: Cutting Effectiveness of Diamond Burs.Braz Oral Sci J.9(1):39

14. Gupta K Ashu, Neha Sharma, Manmohan Bramta.2014.D entin tubular occlusion with bioactive glass containing dentrifice and gluma desensitizer- a comparative SEM evaluation. DJAS 2(1)16-21

15. Hench LL, Anderson O. 1993. Bioactive glasses. In: Hench LL, Wilson $\mathbf{J}$, eds. An Introduction to bioceramics. Singapore: World Scientifc: $45-47$

16. Hill R.An alternative view of the degradation of bioglass.1996. Journal of Material Science Letters;15:112-125

17. Nakabayashi NP, Pashley DH.1998. Hybridization of dental hard tissue, 1st Ed, Chicago IL, Quintenss Publ Co, Ltd,p:1-107

18. Natasha M, Neeraj M, Vikram S, Deepak P, Nidhi M.2001. Tooth remineralization using bioactive glass A novel approach. Journal Academy Advance Dental Research; 2(2): 45-9 
19. Nishiyama N, Asakura T,Suzuki K. 1998. Adhesion mechanism of resin to etcheddentin primed with N-Mgly studied by C NMR, J Biomed Mater Res, 40:458-63

20. Orchardson R, Gillam DG. 2006. Managing dentine hypersensitivity. JADA.,137:990-998.

21. Orchardson R, Gillam DG. 2000. The efficacy of potassium salts as agents for treating dentine hypersensitivity.J Orofac Pain,;14:9-19

22. Orchardson R, Collins WJ. 1987. Clinical features of hypersensitive teeth. Br Dent J. 162(7):253-6.

23. Shelon Cristina S. Pinto.2010. In vitro and analyses of the effect of desensitizing agent on dentin permeability and dentinal tubule occlusion.Journal of oral science.52(1):23-32

24. Mahajan neha. 2015. Effect of citric acid and desinsitizing agrnt application on non-fluorosed and fluorosed dentin : an in vitro SEM study. The open dentistry journal,2015,9,98-102 